Journal of Educational Method and Technology Vol. 2 No. 1, April 2019

P-ISSN 2622-8459 E-ISSN 2622-8467

http://ejournal.unima.ac.id/index.php/jemtec

\title{
The Application Of Cooperative Learning Models To Children At Gmim Kindergarten Hosiana Tumatangtang
}

\author{
${ }^{1}$ N D E Suwaryaningrat \\ ${ }^{1}$ Universitas Negeri Manado, Indonesia \\ corresponding author: nidewiekha@unima.ac.id
}

\begin{abstract}
This research aimed to make the learning design possible for the development of motor cycle and the coordination of the eyes, hands, brain of the child and carry out the whole plan with the best. Through cooperative learning methods can improve the fine motor skills of children from an average result of fine motor skills of children in collaborative activities in groups. into a medium used in a game with the aim that children can train their fine motor skills. Through this game children are invited to be able to develop creativity through collaborative activities and can develop fine motor skills through these learning activities. This study uses the Classroom Action Research (CAR) approach according to the Kemmis model and MC Taggart. According to Kemmis and Mc Taggart (in Yunus, 2009: 105) describe action research as a set that aims to improve and evaluate decisions and actions aimed at implementing these actions. The discussion of the results of the study was directed at the implementation of the research cycle I and cycle II by following the 4 stages of research, namely planning, action, observation and reflection. Thus the learning achievement of children is $82 \%$ of the target of $80 \%$ who are successful, so this study in class II action research was declared successful and no longer needed to be continued in the next cycle. Finally, It can be conclude that Cooperative learning can add insight to the teacher in choosing the right learning model to be applied in class according to the objectives of each learning that will be carried out.
\end{abstract}

Keywords: Application; Cooperative Learning Models; Children; Kindergarten

\section{Introduction}

Law No. 20 of 2003 describes that: Early childhood education or PAUD is a coaching effort aimed at children from birth to the age of six years, which is carried out through the provision of educational stimulation to help growth and physical and spiritual development so that children have readiness in entering further education.

"Early childhood is an individual who experiences a process of rapid growth and development even said to be a developmental leap, early age is also said to be a creative period" (Yulani Nurani Sujiono, 2005: 134) which is believed that the creativity shown by children is an orginal form of creativity the appearance seems uncontrollable. This age is a unique phase of life with its distinctive characteristics, 
both physically and psychologically. These characteristics are characterized by the child's learning ability that is extraordinary the ability of children to learn actively and exploratively.

This development is closely related to the development of motor centers in the brain where this motor development can help the physical growth of early childhood, therefore many experts claim that the development of motor skills is closely related to abilities such as cognitive, social, and emotional development of the child so the teacher need to develop the child's motor skills so that children can grow well. Learning education in PAUD aims to help lay the foundation towards the development of attitudes of knowledge, skills, creativity and prepare children to enter basic education by developing religious, physical, motoric, cognitive, language, social emotional and artistic values.

In language development in early childhood communication media so that children can become part of their social groups. Language can be used in the form of oral, image, writing, numbers and art. The ability to work together can stimulate children's fine motor skills, coordinate their eyes with their hands and train flexibility, flexibility, and train their concentration in doing activities to enable children to develop motor skills so that learning can be performed maximally. Not only training gross motor skills is superior, but fine motor skills can also be noticed.

Based on the opinions above, it can be seen that fine motoric children must be noticed. To make the learning design possible for the development of motor cycle and the coordination of the eyes, hands, brain of the child and carry out the whole plan with the best. Through cooperative learning methods can improve the fine motor skills of children from an average result of fine motor skills of children in collaborative activities in groups.

Efforts to overcome these problems by applying and improving the ability of cooperation that contains words into a medium used in a game with the aim that children can train their fine motor skills. Through this game children are invited to be able to develop creativity through collaborative activities and can develop fine motor skills through these learning activities. And to overcome the problem above, it is very necessary for the role of teachers and parents in overcoming the problem. One way that teachers do is by using the method of developing creativity in art learning activities so that they can train children to be skilled and creative so that the aspects of fine motoric development can develop children's creativity through the ability to cooperate in groups. Based on the above problems, the researcher will conduct a study with the title of applying cooperative learning models to improve the ability of batik clothing images for children at GMIM TK Hosiana Tumatangtang.

\section{RESEARCH METHODS}

This study uses the Classroom Action Research (CAR) approach according to the Kemmis model and MC Taggart. According to Kemmis and Mc Taggart (in Yunus, 2009: 105) describe action research as a set that aims to improve and evaluate decisions and actions aimed at implementing these actions. Thus the research of 
action suppresses action activities by testing an ID in practice or situation in a micro scale in the hope that these actions can improve and improve the quality of the situation.

\section{Research Results}

The discussion of the results of the study was directed at the implementation of the research cycle I and cycle II by following the 4 stages of research, namely planning, action, observation and reflection. With the implementation of the classroom action research using cooperative learning models to improve the ability to make batik clothing images for children at GMIM Kindergarten Hosiana Tumatangtang 2017-2018 Learning Year turned out to be very satisfying. Learning outcomes of children in learning cycle I have 4 children $(25 \%)$ children get a star sign which means that the four children are categorized as not yet having the ability to make a picture of clothes to improve the ability to make clothes using a cooperative learning model correctly. This shows that there must be special guidance in learning activities. Then there are 6 children (38\%) children get two stars which means that the six children are categorized as developing abilities in batik clothing. In this case, they can already make clothes, but still having difficulty in honing their fine motor skills, the child can still be guided and guided by the teacher in their learning activities. Furthermore, 4 children (25\%) received a three-star sign indicating that the four children were categorized as developing according to expectations in terms of batik clothing, which means that they can make batik images by following the steps and methods presented by the teacher in learning but still grow time to answer teacher questions, so learning must be repeated to improve children's development skills. And 2 children (12\%) get a four-star sign that shows that the two children have the ability to make clothes with a cooperative learning model correctly and are able to answer teacher questions spontaneously even though this child has shown good progress in making batik right and fast by following the steps and ways taught by the teacher in learning activities. Children who get one star and two stars are declared not successful in participating in learning activities in cycle I. In this case there are $10(63 \%)$ children from 16 children who have not shown good progress in terms of the ability to make clothes. then the learning outcomes of children in children who got three stars and four stars were declared successful in following the learning activities in this first cycle. Thus there are 6 (37\%) children from 20 children who were declared successful because they have shown the development of the ability to make clothes. thus the results of children's learning are only around $37 \%$ of the $80 \%$ target so this classroom action research needs to be continued in the next cycle.

Learning outcomes of children in learning cycle II there are no children get one star because students can already make batik clothes. Then there are 3 children $(18 \%)$ children, which means that the three children are categorized as developing the ability to make clothes. This matter, they have been able to make a picture of clothes properly, but they still have difficulty in making a picture of clothes using the 
cooperative learning model. Here the teacher's role must be more affective to the teacher's attention to these children in the form of assisting and giving encouragement to their learning activities.

Then 6 children $(38 \%)$ children showed that the abilities of the six children were categorized as developing according to expectations in terms of batik clothing images which meant they could batik clothes with the method taught by the teacher correctly but still needed time to answer questions from the teacher so learning must be repeated to improve children's abilities. And there are 7 children $(44 \%)$ children, which means that the seven children have had the ability to batik clothing images correctly and are able to answer teacher questions spontaneously. Children who get three stars and four stars are declared successful in participating in learning activities in cycle II. Thus there are 13 children (82\%) of 16 children who were declared successful, because they have shown how to make a picture of clothes using the correct cooperative learning model. Thus the learning achievement of children is $82 \%$ of the target of $80 \%$ who are successful, so this study in class II action research was declared successful and no longer needed to be continued in the next cycle.

\section{Conclusion}

Based on the results of the research that has been carried out by giving several actions from cycles I and II as well as the discussions that have been conducted, it can be concluded that the application of cooperative learning models to improve the drawing ability of children in the GMIM TK Hosiana Tumatangtang. This can be seen from the results of the research carried out in the first cycle has increased in the implementation of learning in cycle II.

The results of the first-class action research were stated to be unsuccessful with an average learning achievement that achieved the success of 6 children (37\%) children of 16 children, with a success target of $80 \%$ so that classroom action research in batik clothing was continued in the next cycle. And the results of the classroom action research cycle II had increased so that it was declared successful with the average learning achievement which included the success of 13 children $(82 \%)$ children of 16 children with a target of $80 \%$ success in the learning process.

The use of cooperative learning models is proven to be able to improve the ability of batik clothing. Because this learning model teaches children to cooperate with other groups. Cooperative learning can add insight to the teacher in choosing the right learning model to be applied in class according to the objectives of each learning that will be carried out. 
Journal of Educational Method and Technology Vol. 2 No. 1, April 2019

P-ISSN 2622-8459 E-ISSN 2622-8467

http://ejournal.unima.ac.id/index.php/jemtec

\section{References}

Aqib Zainal, dkk. 2007. Penelitian Tindakan Kelas untuk Guru SD, SLB, TK.

Bandung : Yrama Widya

Dick dkk. 2013. Model Model Pembelajaran. Jakarta : Pustaka Belajar.

Ean Y Haenila. 2013. Konsorsium Sertifikat Guru. Jakarta : Yrama Widya.

Ean Y Haenila. 2015. Kurikulum Pembelajaran PAUD. Yogyakarta : Media Akademi

Fadlillah Muhammad. 2012. Desain Desain Pembelajaran. Jakarta : Yrama Widya.

Indrijati Herdin. 2016. Psikologi Perkembangan dan Pendidikan Anak usia Dini : Jakarta : Prenadamedia Group.

Jamis Martini, M.Sc. Ed. 2006 . Perkembangan dan Pengembangan Anak Usia

Taman kanak - kanak. Jakarta : PT Gramedia.

Johnson@ Johnson, Lawrence @ Harvey. 2013. Konsorsium Sertifikat Guru. Jakarta : Yrama Widya.

Komara Endang. 2012. Peningkatan dan Tindakan Kelas dan Peningkatan

Profesionalitas Guru. Bandung : Aditama

Martinis Yamin. 2013. Model Model Pembelajaran. Jakarta : Yrama Widya

Muliawan. 2016. Mengembangkan Imajinasi dan Kreatifitas Anak. Yogyakarta. :

PT Gava Media.

Munadi Yudhi, 2013 . Media Pembelajaran. Jakarta. PT Press Group

Permendikbud No. 58. 2009. Indikator Kerjasama Anak Usia Dini. Jakarta :

Permendikbud.

Permendikbud No. 137. 2013. Tentang Standar Nasional Pendidikan Anak Usia Dini.

Jakarta : Permendikbud.

Slavin dkk. 2013. 2013. Konsorsium Sertifikat Guru. Jakarta : Yrama Widya.

Sumadayo. 2013. Penelitian Tindakan Kelas. Jakarta : Yrama Widya.

Sukidin dkk. 2008. Manajemen Penelitian Tindakan Kelas. Jakarta : Insan Cendekia Utami dkk, 2013. Konsorsium Sertifikasi Guru PAUD. Jakarta : Modul PLPG

Yamin Martinis. 2013. Model Model Pembelajaran. Jakarta : Pustaka Belajar. 
Journal of Educational Method and Technology Vol. 2 No. 1, April 2019

P-ISSN 2622-8459 E-ISSN 2622-8467

http://ejournal.unima.ac.id/index.php/jemtec 